\title{
METODE FOTO RENTANG DEKAT (CLOSE RANGE PHOTOGRAMMETRY) DAN AERIAL UNTUK PENDOKUMENTASIAN TIGA DIMENSI CAGAR BUDAYA
}

\author{
Brahmantara \\ Balai Konservasi Borobudur \\ Email : bramantarayk@gmail.com
}

\begin{abstract}
Abstrak: Metode pendokumentasian Cagar Budaya telah mengalami perkembangan yang luar biasa, ditandai dengan adanya teknologi digital dalam sistem perekaman dan akuisisi data. Data visual yang dihasilkan melalui proses pendokumentasian digital tidak hanya memberikan hasil dalam dua dimensi (2D), namun mampu memberikan interpretasi secara tiga dimensi (3D) dengan detail dan akurasi yang cukup tinggi. Salah satu metode yang berkembang saat ini adalah fotogrametri digital, baik close range photogrammetry (foto rentang dekat) dan aerial photogrammetry (foto udara) dengan wahana pesawat tanpa awak (drone).

Kajian metode foto rentang dekat (close range photogrammetry) dan foto udara ini merupakan salah satu metode pendokumentasian yang murah (low cost methodology) apabila dibandingkan dengan pemindaian menggunakan instrumen $3 D$ laser scanning. Berdasarkan kelebihan tersebut, maka perlu dikaji efektifitas metode ini untuk pendokumentasin Cagar Budaya berdasarkan tingkat/nilai akurasi yang dihasilkan.

Hasil pengolahan dan analisis data menunjukkan bahwa hasil pendokumentasian dan pemodelan tiga dimensi relief kapal Candi Borobudur menggunakan metode foto rentang dekat (close range photogrammetry) dengan kontrol skala menghasilkan nilai akurasi sebesar $5 \mathrm{~mm}$, stupa terbuka dan arca singa masing-masing $3 \mathrm{~mm}$ dan 1,6 $\mathrm{mm}$. Sedangkan hasil pemodelan Candi Borobudur dengan data foto udara wahana pesawat tanpa awak menghasilkan nilai akurasi sebesar 4 $\mathrm{cm}$. Dari hasil tersebut dapat diketahui bahwa metode foto rentang dekat dan foto udara menghasilkan tingkat akurasi yang cukup tinggi dan nilai RMS error yang rendah, sehingga kedua metode ini layak digunakan dalam pendokumentasian tiga dimensi Cagar Budaya dengan biaya murah.
\end{abstract}

Kata kunci : tiga dimensi (3D),Terestrial Laser Scanner, foto rentang dekat (close range photogrammetry), aerial photogrammetry (foto udara), Cagar Budaya

Abstract: The method of documenting the cultural heritage has undergone tremendous development, with the presence of digital technology in data recording and acquisition systems. Visual data generated through the process of digital documentation is not only capable of delivering results in two-dimensional visuals (2D), but provides interpretation in $3 \mathrm{D}$ visuals with accurate detail and accuracy. One of the methods that can be developed is digital photogrammetry, both close range photogrammetry and aerial photogrammetry produced by UAV.

The study of close range photogrammetry and aerial photo method is one of the low cost methodology compared to $3 \mathrm{D}$ laser scanning, so it is necessary to study the effectiveness of this method for documentation of cultural heritage based on the value of the accuracy produced.

The results from data processing and analysis show that the results of three-dimensional documentation and modeling (3D) with close-range photogrammetry method for ships relief of Borobudur Temple using scale bar control yields an accuracy of $5 \mathrm{~mm}$, the open stupa and the lion statue have successive accuracy about $3 \mathrm{~mm}$ and $1.6 \mathrm{~mm}$. The Borobudur Temple model generated from aerial photogrammetry by UAV yield an accuracy value of $4 \mathrm{~cm}$. Based on these results, the close range and aerial photogrammetry produced high accuracy value with low RMS error. These methods are feasible to be used at a low cost in documenting and three dimensional modeling of cultural heritage.

Keywords: three dimensional (3D), Terrestrial Laser Scanner, close range photogrammetry, aerial photogrammetry (aerial photography), cultural heritage 


\section{PENDAHULUAN}

\subsection{Latar Belakang}

Teknologi pendokumentasian Cagar Budaya berbasis tiga dimensi (3D) yang berkembang di Indonesia saat ini menggunakan teknologi Terrestrial Laser Scanning (TLS). Penggunaan instrumen Terrestrial Laser Scanning untuk pendokumentasian Cagar Budaya masih sangat terbatas penggunaannya, karena harga alat yang mahal dan terbatasnya perangkat lunak (software) yang digunakan. Di Indonesia, baru terdapat 3 institusi pemerintah di bidang kebudayaan yang menggunakan alat tersebut. Balai Konservasi Borobudur adalah salah satu institusi yang telah menggunakan instrumen tersebut sejak tahun 2005. Instrumen laser scanner memiliki harga yang sangat mahal, yang menjadikannya sebagai sebuah hambatan untuk rencana pengembangan pendokumentasian dan pemodelan tiga dimensi Cagar Budaya di seluruh Indonesia. Dengan kondisi tersebut perlu dikembangkan metode pendokumentasian berbasis tiga dimensi yang lebih murah, namun menghasilkan tingkat akurasi data yang baik atau setidaknya mendekati akurasi yang dihasilkan oleh instrumen laser scanner. Salah satu metode yang bisa dikembangkan adalah pendokumentasian tiga dimensi berbasis foto, yaitu dengan teknik Foto Rentang Dekat (Close Range Photogrammetry/CRP) dan Foto Udara (Aerial Photogrammetry) menggunakan wahana pesawat tanpa awak atau Unmanned Aerial Vehicle (UAV).

Fotogrametri rentang dekat menggunakan prinsip dasar pengukuran tumpang tindih antar foto dengan sudut pandang yang berbeda dan pengukuran orientasi kamera. Model tiga dimensi yang dihasilkan sangat dipengaruhi oleh banyaknya area tampalan antar foto. Kalibrasi pada kamera non metrik menggunakan bantuan komputerisasi sehingga dapat diketahui parameter kamera dan lokasi kamera, selanjutnya didapat nilai hasil pengukuran orientasi kamera (Aulejtner, 2011 dalam Hendy, 2014). Kalibrasi kamera dilakukan untuk menentukan parameter internal kamera yang meliputi: principal distance $(\mathrm{c})$, titik pusat fidusial foto $\left(\mathrm{x}_{\mathrm{o}}, \mathrm{y}_{\mathrm{o}}\right)$, distorsi lensa $\left(\mathrm{K}_{1}, \mathrm{~K}_{2}, \mathrm{~K}_{3}, \mathrm{P}_{1}\right.$ and $\left.\mathrm{P}_{2}\right)$, serta distorsi akibat perbedaan penyekalaan dan tingkat tegak lurus antara sumbu X dan $\mathrm{Y}\left(\mathrm{b}_{1}, \mathrm{~b}_{2}\right)$ (Fraser, 1998).
Kamera yang digunakan dalam kajian ini adalah kamera non-metrik, sehingga diperlukan kalibrasi. Kalibrasi dilakukan menggunakan frame target dari perangkat lunak Agisoft Photoscan. Pemotretan dilakukan mengelilingi frame kalibrasi untuk satu set data dengan sudut perpindahan kamera optimum yaitu $90^{\circ}$ (Wotjas, 2010). Pengambilan foto bertampalan dipengaruhi oleh bentuk obyek yang akan dibuat model tiga dimensinya.

Beberapa contoh pengambilan obyek foto untuk pemodelan tiga dimensi adalah pemotretan $360^{\circ}$ dan pemotretan sejajar. Untuk menghasilkan model tiga dimensi yang baik, pemotretan $360^{\circ}$ (Gambar I.1) dilakukan dengan cara mengelilingi obyek dengan jarak dan ketinggian yang sama.

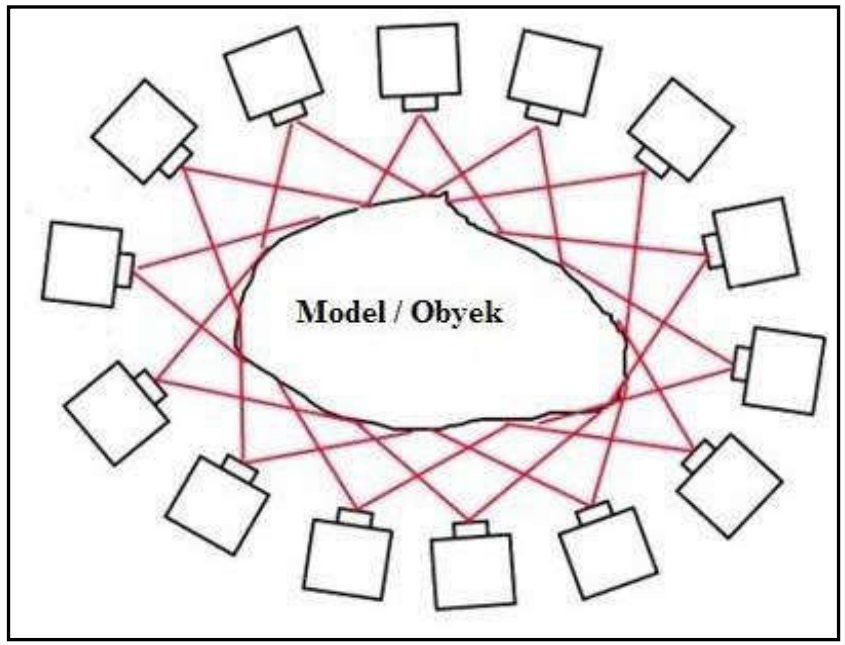

Gambar I.1. Pemotretan obyek $360^{\circ}$

Pemotretan sejajar seperti yang ditunjukkan dalam Gambar I.2, dilakukan dengan posisi yang sejajar dengan obyek, jarak foto berdekatan satu sama lain, dan sudut rendah (Walford, 2013 dalam Hendy, 2014). Pemotretan obyek $360^{\circ}$ dilakukan pada arca Buddha, sedangkan pemotretan obyek sejajar dilakukan pada relief Candi Borobudur.

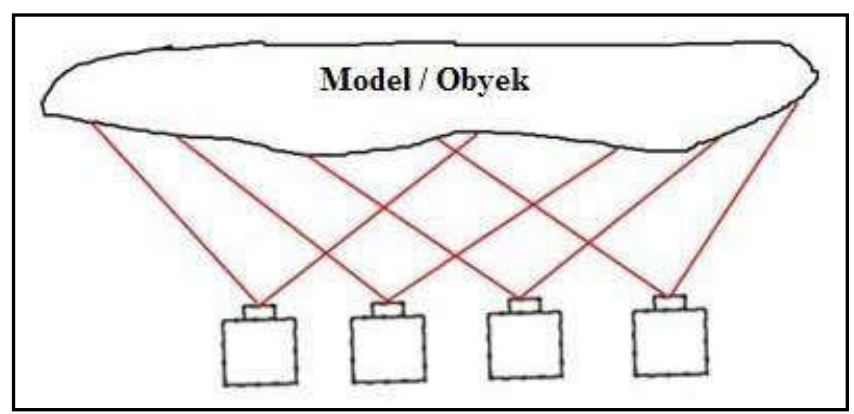

Gambar I.2. Pemotretan obyek sejajar 
Foto udara adalah rekaman fotografis obyek di atas permukaan tanah yang pengambilannya dilakukan dari udara (Suharsana, 1999). Foto udara pada umunya dibedakan atas foto vertikal dan foto condong. Foto udara vertikal dibuat dengan sumbu kamera yang arahnya dibuat setegak mungkin dengan obyek, seperti yang terlihat pada Gambar I.3.

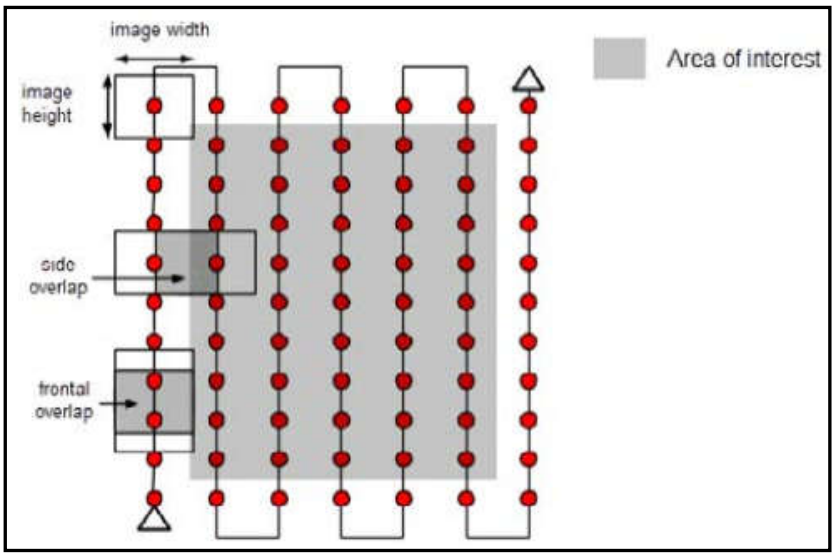

Gambar I.3. Pengambilan foto udara tegak

Karena pergerakan pesawat, foto udara yang dihasilkan tidak benar-benar vertikal. Kemiringan sumbu kamera untuk foto tegak maksimal $3^{\circ}$. Foto udara condong dibuat dengan sumbu kamera yang sengaja diarahkan menyudut terhadap sumbu vertikal, seperti yang ditunjukkan pada Gambar I.4.

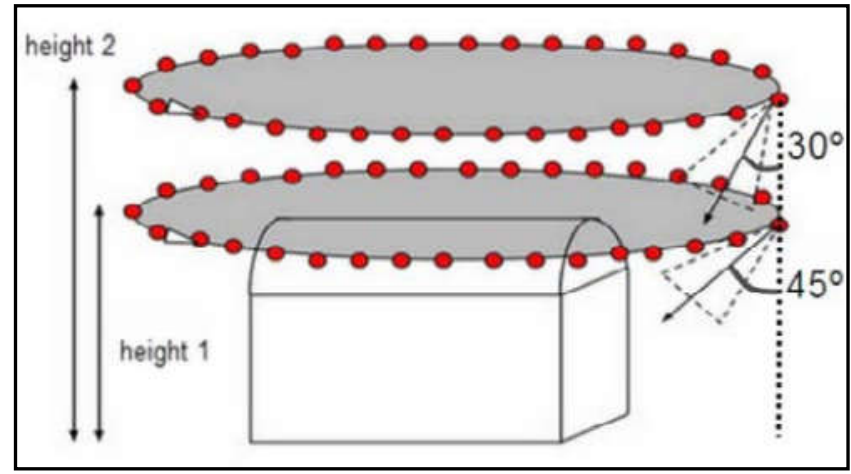

Gambar I.4. Pengambilan foto udara condong

Kamera non metrik memerlukan kalibrasi untuk menghasilkan model tiga dimensi dengan akurasi yang baik. Kalibrasi kamera dilakukan sebelum dan setelah pemotretan obyek. Hasil dari kalibrasi berupa parameter yang menunjukkan koefisien koreksi lensa kamera. Kalibrasi berlaku untuk tiap panjang fokus dan jarak obyek tertentu, sehingga apabila terdapat perubahan maka harus dilakukan kalibrasi. Dengan kondisi tersebut, maka posisi kamera tidak harus melihat dengan sudut pandang paralel dan konfigurasi stereo. Foto dengan berbagai macam posisi mulai dari menyebar, horizontal, vertikal atau miring dapat digunakan apabila saling bertampalan. Posisi kamera secara otomatis akan terdeteksi melalui proses komputerisasi dengan menggunakan perangkat lunak Agisoft Photoscan.

Maksud kajian ini adalah melakukan kajian terhadap metode pendokumentasian dan pemodelan tiga dimensi Cagar Budaya yang murah (low cost methodology) berbasis foto. Sedangkan tujuannya adalah mengetahui tingkat akurasi model tiga dimensi yang dihasilkan dari teknik foto rentang dekat dan foto udara dengan wahana pesawat tanpa awak (UAV). Manfaat kajian yang diharapkan adalah meningkatkan kemampuan teknis tenaga dokumentator dalam bidang pendokumentasian Cagar Budaya. Selain itu, dapat diperoleh metode pendokumentasain tiga dimensi yang relatif murah, efektif, dan efisien, mengingat bahwa pendokumentasian Cagar Budaya secara tiga dimensi saat ini masih terbatas pada penggunaan instrumen 3D laser scanning yang memakan biaya cukup mahal.

\subsection{Metode Penelitian}

Tahap persiapan dimulai dengan mempersiapkan alat dan bahan sebagai pendukung pengambilan data di lapangan serta instrumen pendukung pengolahan data (post processing). Adapun alat dan bahan yang digunakan pada kajian ini adalah sebagai berikut:

1) Perangkat keras pendukung pengambilan data:

a. Workstation untuk pengolahan data

b. Marker (target)

2) Perangkat keras dan lunak pengambilan data foto:

a. Quadcopter tipe Phantom 3 Advanced untuk pengambilan foto udara,

b. Kamera DSLR untuk pengambilan foto rentang dekat dengan spesifikasi perangkat:

a) Canon EOS 5D MK II,Tipe Full Frame Digital SLR

b) Lensa 24 - $70 \mathrm{f} / 4$ L IS USM

3) Peralatan pengukuran :

a. Total Station tipe LEICA TCR 805 Ultra

b. 3D Laser scanning Leica Scan Station C 10

4) Perangkat lunak pengolahan data :
a. Agisoft Photosan
b. Cloud Compare 
Tahap pengumpulan data terdiri dari:

a. Pengukuran titik kontrol obyek

Pengukuran titik kontrol pada relief dan arca menggunakan meteran (Gambar II.1) dan menggunakan Total Station (gambar II.2). Data hasil pengukuran ini digunakan sebagai data pembanding dimensi asli obyek dengan model tiga dimensi yang dihasilkan.

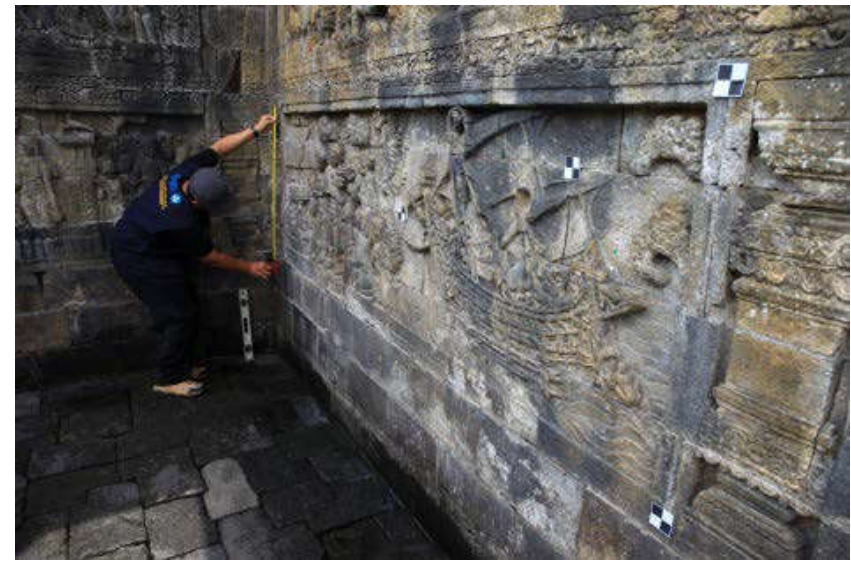

Gambar II.1. pengukuran titik kontrol relief dengan meteran

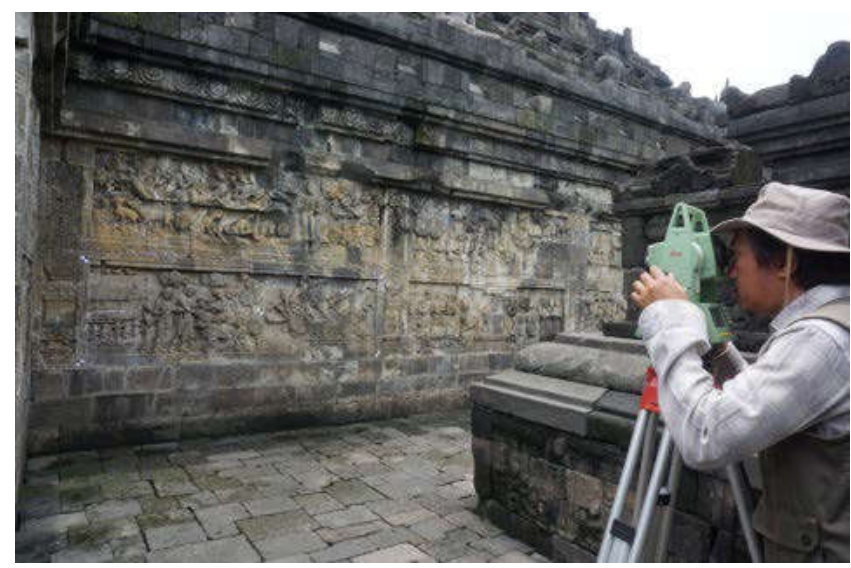

Gambar II.2. pengukuran titik kontrol relief dengan Total Station

b. Pengukuran titik kontrol tanah (Ground Control Points)

Pengukuran perbandingan jarak dan dimensi untuk data Candi Borobudur menggunakan data dari instrument terrestrial 3D laser scanning yang sudah dilakukan sebelumnya, sedangkan pengukuran titik kontrol tanah (Ground Control Points) menggunakan Total Station (Gambar II.3). Hasil pengukuran titik kontrol digunakan sebagai data pembanding antara obyek dan model tiga dimensi yang dihasilkan.
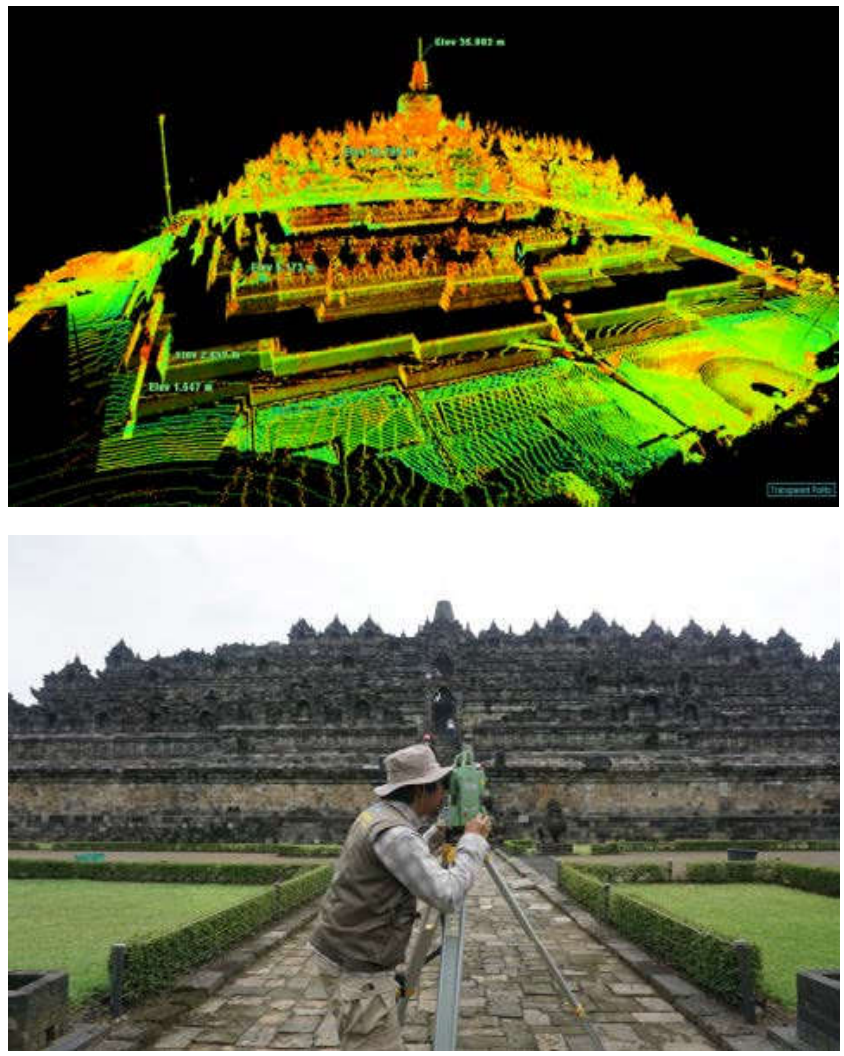

Gambar II.3. pengukuran 3D Laser scanning dan Total Station

c. Pengambilan Foto Rentang Dekat (Close Range Photogrametry)

Pengambilan foto dilakukan sejajar dengan bidang obyek dengan area yang bertampalan sekitar 80\% tiap fotonya. Untuk memperkuat geometri obyek, maka kamera diputar sekitar $35^{\circ}$ pada tiap titik berdiri, sehingga dapat mencakup area disekitarnya, seperti terlihat dalam ilustrasi Gambar II.4.

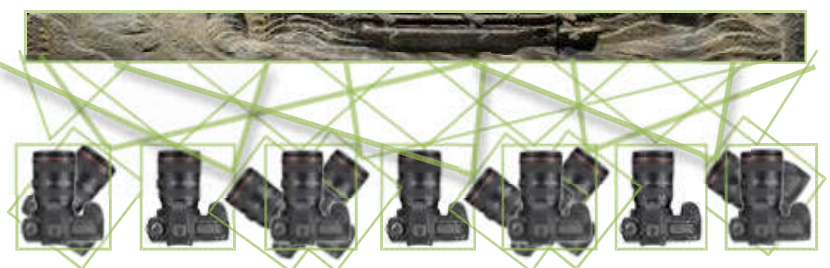

Gambar II.4. posisi kamera pada pengambilan foto pada relief candi Borobudur

Untuk pengambilan data foto stupa terbuka, geometri pengambilan datanya berupa lingkaran konsentris dengan sumbu utama kamera tegak lurus dinding stupa. Pengambilan data foto dilakukan dalam dua tahap, yaitu tahap pertama mencakup $3 / 4$ bagian bawah stupa, dan tahap kedua mencakup $3 / 4$ bagian atas stupa seperti terlihat dalam ilustrasi Gambar II.5. 


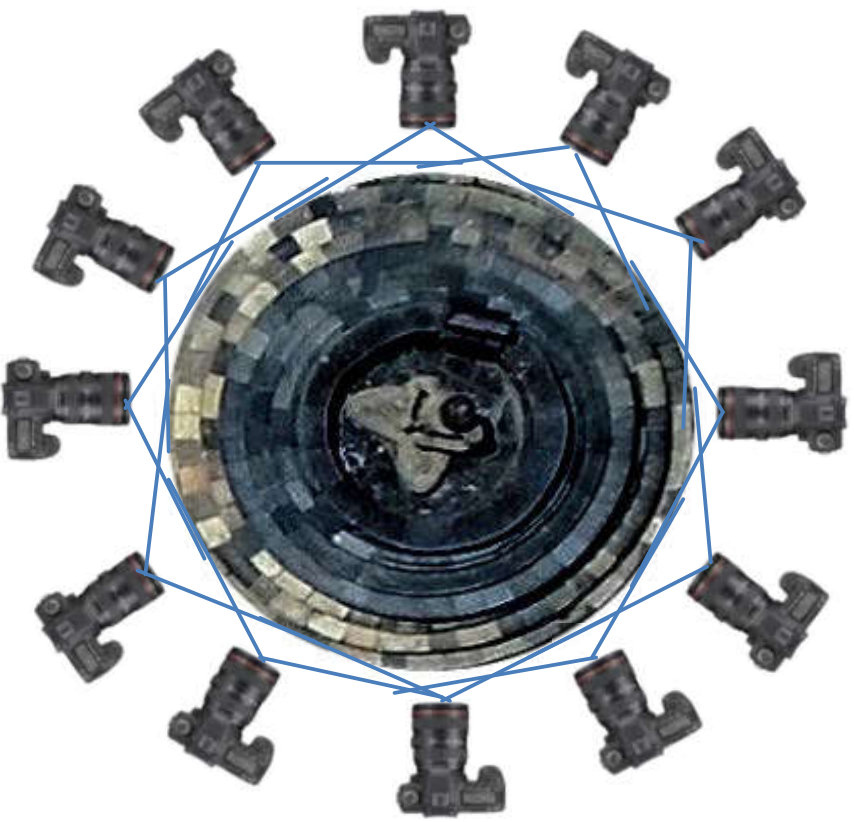

Gambar II.5. posisi kamera pada pengambilan foto terbuka Candi Borobudur d. Pengambilan Foto Udara (Aerial Photos) dengan $U A V$

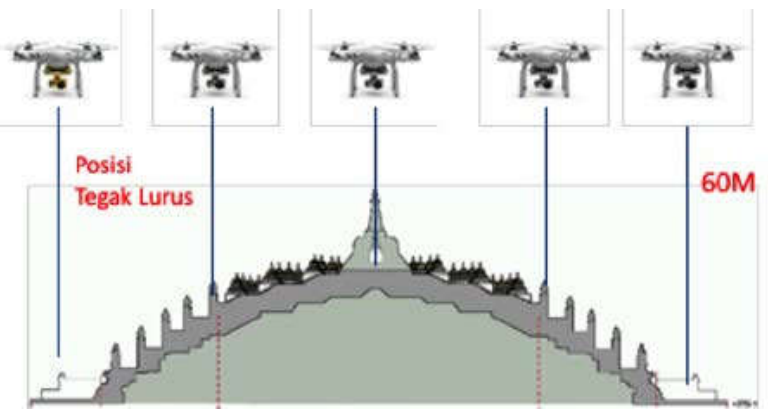

Gambar II.6. pengambilan foto udara vertical

Pengambilan foto secara vertikal dilakukan dengan cara memposisikan sumbu utama kamera tegak lurus dengan permukaan candi seperti terlihat pada Gambar II.6. Posisi ketinggian pesawat berada pada ketinggian $60 \mathrm{~m}$. Pengambilan data foto udara Candi Borobudur dilakukan dengan perencanaan jalur sebanyak 8 grid, tampalan foto $80 \%$, dan menghasilkan foto sebanyak 119 foto dengan posisi jalur seperti pada Gambar II.6 di bawah:

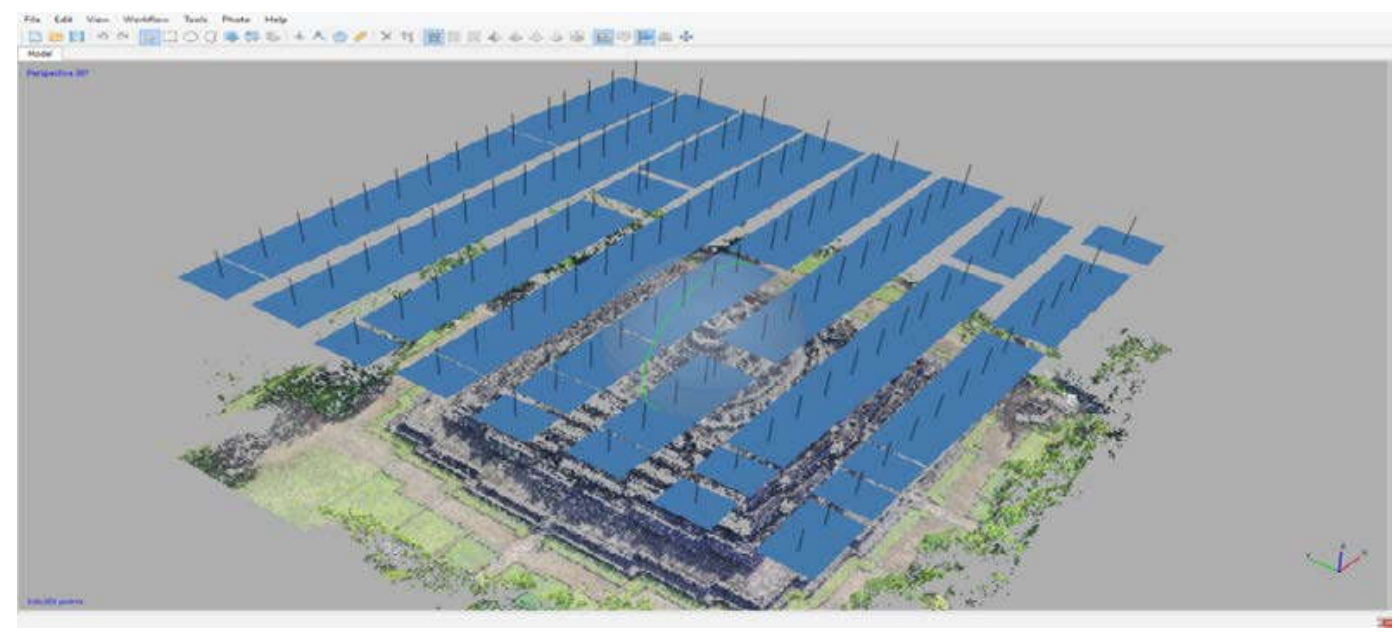

Gambar II.6. posisi jalur terbang pengambilan foto udara

\subsection{Tahap Pengolahan Data}

a. Pre-processing foto

Tahap ini bertujuan untuk mengetahui kualitas foto udara yang dihasilkan. Pengecekan foto dilakukan secara manual dengan mempertimbangkan beberapa hal, diantaranya adalah: kelengkapan foto untuk area yang dipetakan, adanya gap pada foto, gambar berbayang, tampalan tidak maksimal, gambar miring, dan lain-lain. b. Input data kalibrasi kamera

Hasil kalibrasi kamera digunakan sebagai data pendekatan awal, untuk kemudian dihitung kembali oleh Agisoft PhotoScan untuk mendapatkan parameter orientasi dalam yang sesuai dengan keadaan saat foto diambil. Parameter tersebut selanjutnya digunakan pada proses pengolahan foto selanjutnya. 


\section{c. Alignment foto}

Proses alignment foto dilakukan dengan menggunakan perangkat lunak Agisoft PhotoScan. Algoritma yang digunakan perangkat lunak ini adalah dengan mengenali titik-titik yang mempunyai kesamaan nilai piksel. Piksel dengan nilai yang sama akan didefinisikan sebagai tie points.

d. Pembuatan dense cloud

Pembuatan dense cloud didasarkan pada perapatan foto disekitar tie point dan penggabungan antar titik berdasarkan nilai tingginya. Dense cloud menampilkan titik-titik yang lebih rapat apabila dibandingkan dengan tie points.

e. Input Ground Control Points (GCP)

Tahap selanjutnya setelah model terbentuk adalah menginput Ground Control Points (GCP) pada model yang telah dibuat. GCP untuk foto udara sebelumnya telah diukur dengan total station sebelum pemotretan udara dilakukan, kemudian diidentifikasi kembali menjadi sebuah marker pada foto udara.

\section{HASIL DAN PEMBAHASAN}

\subsection{Hasil Kalibrasi Kamera}

Metode yang digunakan untuk kalibrasi kamera pada foto rentang dekat dan foto udara menggunakan metode lab calibration dan juga self calibration yang dilakukan secara otomatis bersamaan dengan proses perataan berkas. Lab calibration menggunakan frame target pada perangkat lunak Agisoft photoscan.

\section{Lab calibration Foto Rentang Dekat}

Lab calibration menggunakan frame target dengan jumlah foto sebanyak 84 foto dan pengolahannya menggunakan perangkat lunak Agisoft Photoscan. Data hasil kalibrasi dapat dilihat pada Tabel III.1 sebagai berikut :

\begin{tabular}{|c|c|c|c|}
\hline \multicolumn{4}{|c|}{ Canon EOS 5D Mark II (24 mm) } \\
\hline $\begin{array}{l}\text { Resolution } \\
5616 \times 3744\end{array}$ & Focal Length & $\begin{array}{l}\text { Pixel Size } \\
6.55 \times 6.55 \text { um }\end{array}$ & \\
\hline Type: & Frame & $\mathrm{F}:$ & 3868.35 \\
\hline $\mathrm{Cx}$ & 18.3241 & B1: & 0 \\
\hline Cy. & -38.5402 & B2: & 0 \\
\hline K1: & -0.127643 & P1: & -0.000719443 \\
\hline $\mathrm{K} 2$ : & 0.146983 & P2: & -0.00100636 \\
\hline K3: & -0.0553213 & P3: & 0 \\
\hline K4: & 0 & P4: & 0 \\
\hline
\end{tabular}

Tabel III.1. Hasil kalibrasi foto rentang dekat menggunakan perangkat lunak Agisoft photoscan
Agisoft photoscan juga melakukan kalibrasi diri (self calibration) melalui proses iterasi langsung ketika melakukan perataan berkas. Hasil dari proses kalibrasi diri dapat dilihat pada Tabel III.2 sebagai berikut:

\begin{tabular}{|c|c|c|c|}
\hline \multicolumn{4}{|c|}{$\mathrm{FC} 300 \mathrm{~S}(3.61 \mathrm{~mm})$} \\
\hline \multicolumn{4}{|c|}{119 images } \\
\hline Resolution & Focal Length & Pixel Size & \\
\hline $4000 \times 3000$ & $3.61 \mathrm{~mm}$ & $1.56 \times 1.56 \mathrm{um}$ & \\
\hline Type: & Frame & $F:$ & 2644.53 \\
\hline $\mathrm{Cx}$ & 10.8727 & B1: & 0 \\
\hline Cy. & -115.62 & B2: & 0 \\
\hline K1: & -0.00882007 & P1: & 0.000453045 \\
\hline K2: & 0.0182226 & P2: & -0.00117748 \\
\hline Кз: & 0.00657279 & P3: & 0 \\
\hline K4: & 0 & P4: & 0 \\
\hline
\end{tabular}

Tabel III.2. Hasil kalibrasi kalibrasi diri (self calibration) menggunakan perangkat lunak Agisoft photoscan

\section{Field calibration Foto Udara}

Field calibration menggunakan titik Ground Control Point (GCP) sebanyak 6 titik dengan jumlah foto udara sebanyak 119 foto dan pengolahan menggunakan perangkat lunak Agisoft photoscan. Data hasil kalibrasi dapat dilihat pada Tabel III.3 sebagai berikut :

$\begin{array}{llll}\begin{array}{l}\text { FC300S }(3.61 \mathrm{~mm}) \\ 119 \text { images }\end{array} & & & \\ \begin{array}{l}\text { Resolution } \\ \mathbf{4 0 0 0 \times 3 0 0 0}\end{array} & \begin{array}{l}\text { Focal Length } \\ \mathbf{3 . 6 1} \mathbf{m m}\end{array} & \begin{array}{l}\text { Pixel Size } \\ \mathbf{1 . 5 6 \times 1 . 5 6} \mathbf{u m}\end{array} \\ & & & \\ \text { Type: } & \text { Frame } & \text { F: } & 2644.53 \\ \text { Cx } & 10.8727 & \text { B1: } & 0 \\ \text { Cy: } & -115.62 & \text { B2: } & 0 \\ \text { K1: } & -0.00882007 & \text { P1: } & 0.000453045 \\ \text { K2: } & 0.0182226 & \text { P2: } & -0.00117748 \\ \text { K3: } & 0.00657279 & \text { P3: } & 0 \\ \text { K4: } & 0 & \text { P4: } & 0\end{array}$

Tabel III.3 Hasil kalibrasi foto udara menggunakan perangkat lunak Agisoft photoscan

\section{Pembahasan Kalibrasi}

Terdapat perbedaan antara hasil kalibrasi menggunakan frame (lab calibration) dan kalibrasi diri. Hal ini dikarenakan kamera yang digunakan bukan merupakan kamera fix lens, sehingga kemungkinan terjadi perubahan focal length ketika melakukan field calibration dengan fitur lensa autofokus. Jumlah foto yang diambil pada lab calibration lebih banyak, sehingga perubahan focal length lebih sering terjadi karena lensa yang digunakan bukan berjenis fix lens. Kalibrasi diri (self calibration) dianggap lebih baik daripada lab 
calibration karena proses kalibrasi dilakukan sesaat sebelum pengambilan data sehingga parameter kalibrasi kamera yang dicari sesuai dengan kondisi ketika pengambilan data.

\subsection{Hasil Pemodelan Tiga Dimensi}

1. Foto Rentang Dekat

a. Relief Kapal Candi Borobudur

Dari hasil perataan berkas dan pemodelan tiga dimensi secara komputerisasi, didapatkan nilai Root Mean Square Error (X,Y dan Z error), yang menunjukkan perbedaan antara titik kontrol hasil dari pengukuran menggunakan meteran dengan hasil pengukuran koordinat sebenarnya (koordinat tanah) pada titik yang sama. Analisis perbandingan juga dilakukan terhadap hasil pemodelan dan perataan berkas antara model yang menggunakan dan tidak menggunakan parameter hasil kalibrasi lensa, yang hasilnya dapat dilihat pada Tabel III.4a, III.4b, III.5a, dan III.5b sebagai berikut :

Tabel III.4a. Hasil Perataan Berkas dan Pemodelan 3D Relief Kapal dengan kontrol GCP dan kamera lab calibration

\begin{tabular}{|c|c|c|c|c|c|}
\hline Label & $X Y$ error $(m)$ & $Z$ error $(m)$ & Error (m) & Proyeksi & Error (pix) \\
\hline Point 1 & 0.0078752 & 0.011323 & 0.013793 & 23 & 0.988 \\
\hline Point 2 & 0.0084650 & 0.004494 & 0.009584 & 23 & 0.840 \\
\hline Point 3 & 0.0091684 & 0.024873 & 0.026509 & 23 & 0.810 \\
\hline Point 4 & 0.0118115 & 0.013532 & 0.017962 & 23 & 1.196 \\
\hline Point 5 & 0.0063610 & -0.025083 & 0.025877 & 23 & 0.749 \\
\hline Point 6 & 0.0081865 & -0.029141 & 0.030269 & 23 & 0.613 \\
\hline RMSE Total & 0.0088008 & 0.020118 & $0.021959(2 \mathrm{~cm})$ & 138 & 0.886 \\
\hline
\end{tabular}

Tabel III.4b. Hasil Perataan Berkas dan Pemodelan 3D Relief Kapal dengan kontrol skala dan kamera lab calibration

\begin{tabular}{|l|r|r|}
\hline \multicolumn{1}{|c|}{ Label } & Distance (m) & error $(\mathbf{m})$ \\
\hline Point 1 - point 2 & 0.84457 & 0.0045772 \\
\hline Point 3 - point 4 & 0.83632 & 0.0063201 \\
\hline Point 1 - point 3 & 2.70448 & -0.0005156 \\
\hline Point 4 - point 5 & 1.32909 & -0.0009116 \\
\hline Point 3 - point 6 & 0.44496 & -0.0001044 \\
\hline Point 1 - point 5 & 1.50055 & -0.0094516 \\
\hline & RMSE Total & $\mathbf{0 . 0 0 5 0 2 2 2}(\mathbf{5} \mathbf{~ m m})$ \\
\hline
\end{tabular}

Tabel III.5a. Hasil Perataan Berkas dan Pemodelan 3D Relief Kapal dengan kontrol GCP dan skala serta kamera self calibration

\begin{tabular}{|c|c|c|c|c|c|}
\hline Label & $X Y$ error $(m)$ & $Z$ error $(m)$ & Error (m) & Proyeksi & Error (pix) \\
\hline Point 1 & 0.0078797 & 0.011324 & 0.013796 & 23 & 0.991 \\
\hline Point 2 & 0.0084693 & 0.004494 & 0.009588 & 23 & 0.838 \\
\hline Point 3 & 0.0091710 & 0.024873 & 0.026510 & 23 & 0.811 \\
\hline Point 4 & 0.0118131 & 0.013533 & 0.017963 & 23 & 1.196 \\
\hline Point 5 & -0.0063606 & -0.025085 & 0.025878 & 23 & 0.749 \\
\hline Point 6 & -0.0081850 & -0.029141 & 0.030268 & 23 & 0.614 \\
\hline RMSE Total & 0.00880274 & 0.020119 & $0.021960(2 \mathrm{~cm})$ & 138 & 0.886 \\
\hline
\end{tabular}


Tabel III.5b. Hasil Perataan Berkas dan Pemodelan 3D Relief Kapal dengan kontrol skala dan kamera self calibration

\begin{tabular}{|c|c|c|}
\hline Label & Distance (m) & error $(m)$ \\
\hline Point 1 - point 2 & 0.84412 & 0.0041200 \\
\hline Point 3 - point 4 & 0.83600 & 0.0060057 \\
\hline Point 1 - point 3 & 2.70457 & -0.0004314 \\
\hline Point 4 - point 5 & 1.32927 & -0.0007302 \\
\hline Point 3 - point 6 & 0.44496 & $-0,0000935$ \\
\hline Point 1 - point 5 & 1.50068 & -0.0093204 \\
\hline \multicolumn{2}{|c|}{ RMSE Total } & $0,004840(4,8 \mathrm{~mm})$ \\
\hline
\end{tabular}

Dari hasil proses perataan berkas dan pembentukan model tiga dimensi relief kapal Candi Borobudur menghasilkan data point cloud,

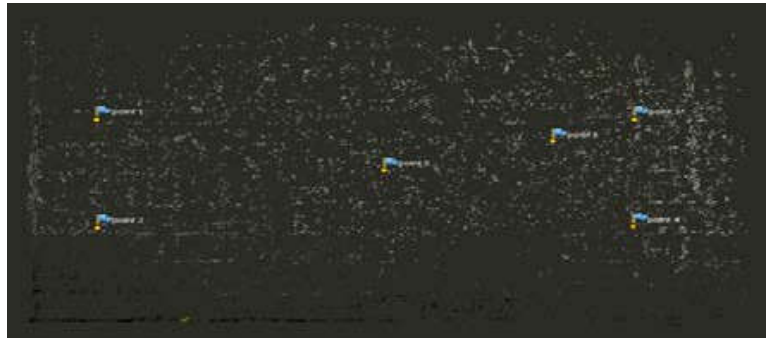

(a)

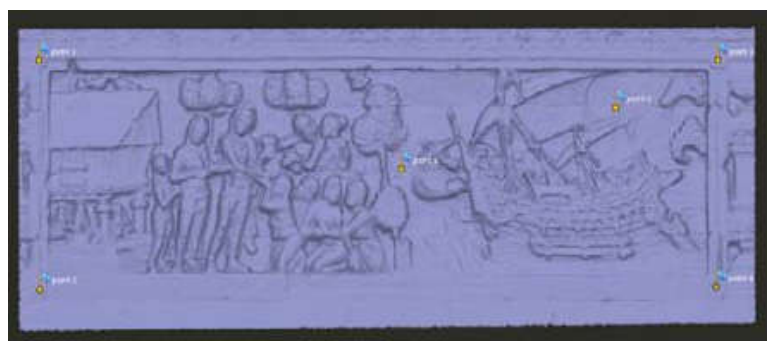

(c) dense point cloud, mesh, dan tekstur. Hasil tersebut dapat dilihat pada Gambar III.1 sebagai berikut

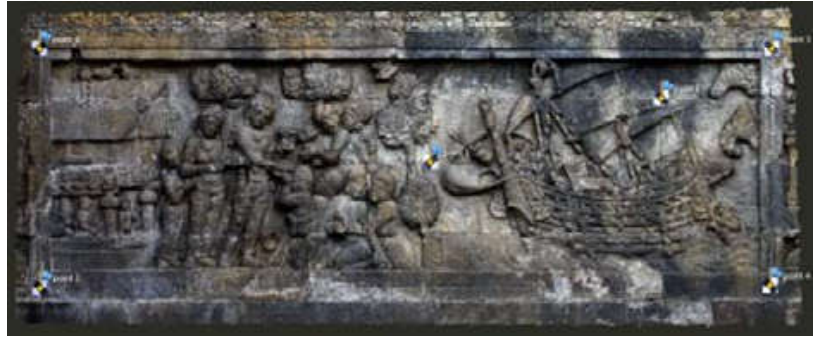

(b)

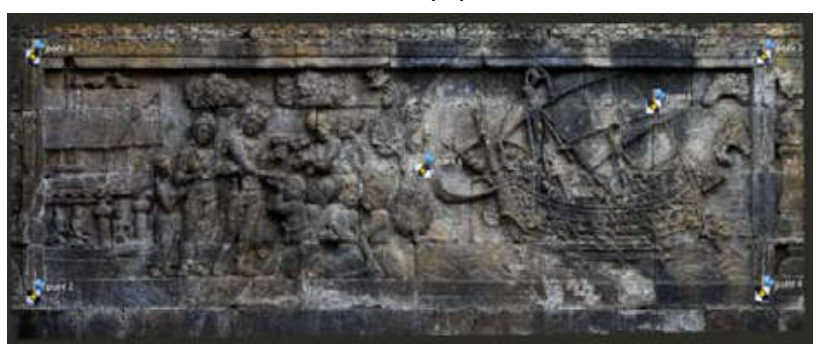

(d)

Gambar III.1. hasil pemodelan tiga dimensi relief Kapal Candi Borobudur (a) point clouds, (b) dense clouds, (c) mesh format, (d) tekstur

Hasil pemodelan tiga dimensi (3D) relief kapal Candi Borobudur dengan posisi kamera terkalibrasi dan kontrol menggunakan GCP dan kontrol skala diperoleh nilai total error sebagai berikut :

1. Posisi kamera dengan lab calibration didapatkan nilai total error piksel dibawah $1 \mathrm{~cm}$, yaitu 0,88; sedangkan RMSE dengan kontrol GCP sebesar $\mathbf{0 . 0 2 1 9 5 9} \mathrm{m}$. Nilai RMSE dengan menggunakan skala sebagai kontrol jarak diperoleh nilai error yang sangat kecil, yaitu $\mathbf{0 . 0 0 5 0 2} \mathrm{m}$.

2. Posisi kamera dengan self calibration didapatkan nilai total error piksel dibawah 1 cm, yaitu : 0,88; sedangkan RMSE dengan kontrol GCP sebesar $\mathbf{0 . 0 2 1 9 6 0 ~ m . ~ N i l a i ~}$ RMSE error dengan menggunakan skala bar sebagai kontrol jarak diperoleh nilai erroryang sangat kecil yaitu $\mathbf{0 , 0 0 4 8 4 0} \mathrm{m}$.

Dari kedua nilai error tersebut dapat diketahui bahwa nilai error hasil foto rentang dekat menggunakan kontrol skala bar mempunyai nilai error sebesar $\mathbf{5} \mathbf{~ m m}$ pada kamera dengan lab calibration dan 4,8 $\mathrm{mm}$ pada kamera dengan self calibration. Nilai dibawah $1 \mathrm{~cm}$ ini sangat dimungkinkan mengingat proses pengambilan foto yang dilakukan menghasilkan tampalan yang cukup rapat, 
posisi jarak titik pengambilan antara 1 foto dengan foto lainnya juga cukup konsisten (Gambar III.2).

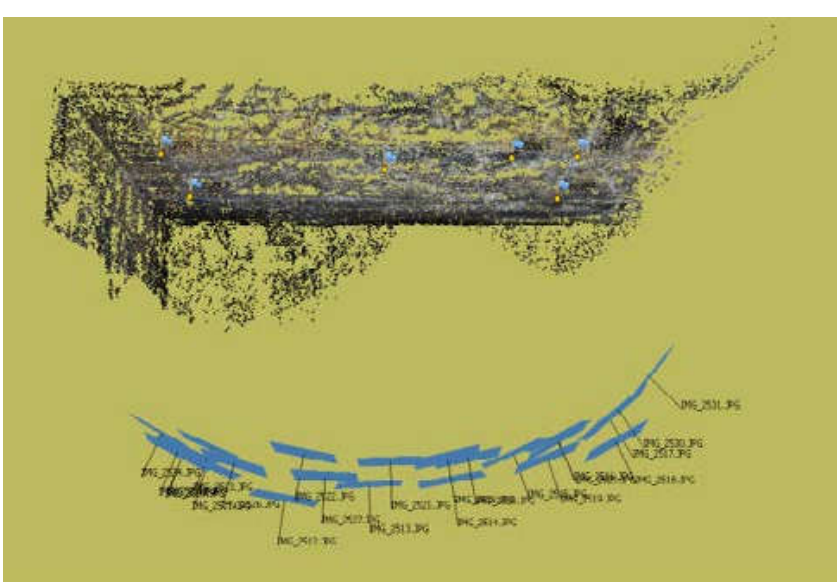

Gambar III.2. posisi kamera pada pengambilan foto relief kapal

\section{b. Stupa teras terbuka Candi Borobudur}

Pengambilan foto dilakukan mengelilingi obyek secara $360^{\circ}$, dengan perkiraan jarak yang hampir sama, dan menggunakan kontrol skala, karena data kontrol menggunakan GCP tidak dilakukan pengukuran. Hasil perataan berkas menggunakan kontrol skala pada stupa teras terbuka mempunyai hasil seperti pada Tabel III.6 di berikut:

Tabel III.6. Hasil Perataan Berkas dan Pemodelan 3D Stupa Teras Terbuka dengan kontrol skala dan kamera lab calibration

\begin{tabular}{|c|c|c|}
\hline Label & $\begin{array}{c}\text { Distance } \\
(\mathbf{m})\end{array}$ & error $(\mathbf{m})$ \\
\hline Point 13 - point 15 & 1.28024 & -0.00375762 \\
\hline Point 15 - point 14 & 1.66936 & 0.00435923 \\
\hline Point 13 - point 14 & 1.68410 & 0.00300092 \\
\hline Point 13 - pusat & 1.05773 & -0.00227076 \\
\hline Point 14 - pusat & 1.08474 & -0.00326020 \\
\hline Point 15 - pusat & 1.22671 & -0.00128911 \\
\hline \multicolumn{2}{|c|}{ RMSE Total } & $0.00315106(\mathbf{3 m m})$ \\
\hline
\end{tabular}

Dari hasil proses perataan berkas dan pembentukan model tiga dimensi stupa teras terbuka menghasilkan data point cloud, dense point cloud, mesh, dan tekstur. Hasil tersebut dapat dilihat pada Gambar III.3 di bawah ini :
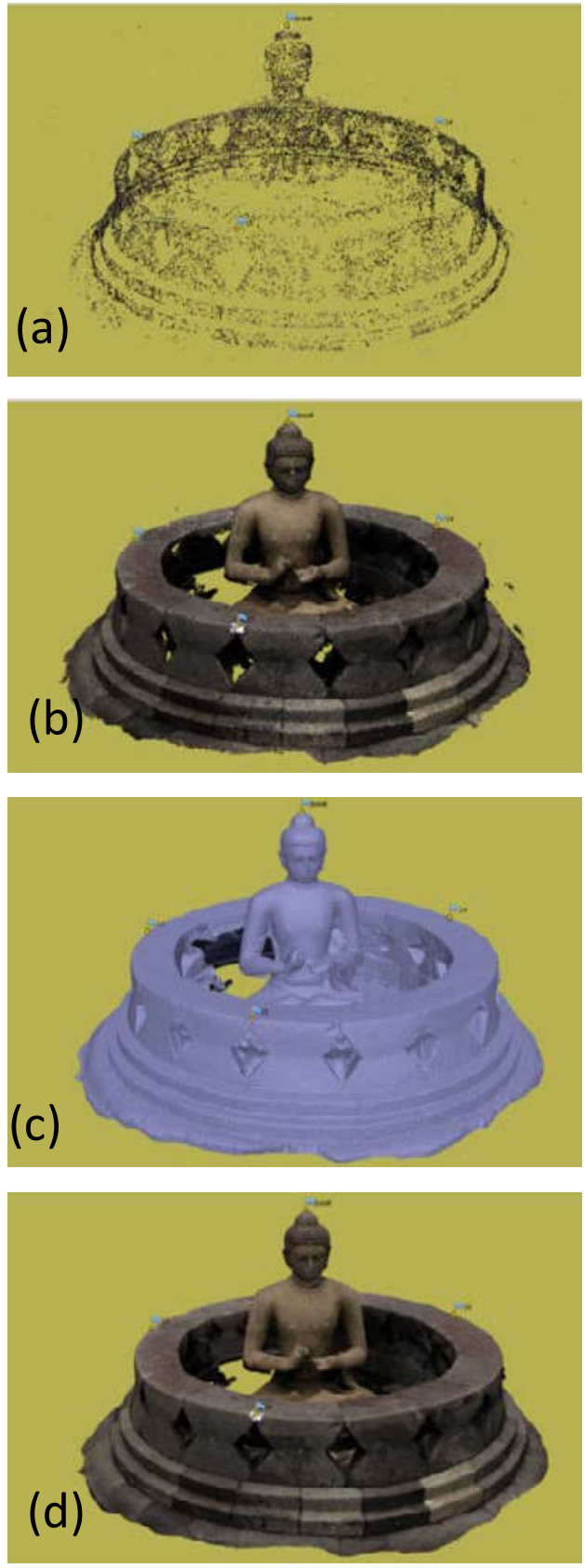

Gambar III.3. hasil pemodelan 3D stupa teras terbuka (a) tie points, (b) dense clouds, (c) mesh format, (d) tekstur

Hasil pemodelan tiga dimensi stupa teras terbuka dengan kamera terkalibrasi dan kontrol menggunakan skala diperoleh nilai total error dibawah $1 \mathrm{~cm}$, yaitu sebesar 0.003151 atau sekitar $3 \mathrm{~mm}$. Nilai yang cukup kecil tersebut dipengaruhi oleh beberapa kondisi dimana kamera yang digunakan lebih stabil, foto yang dihasilkan memiliki resolusi tinggi, focal length yang digunakan tetap, dan jenis sensor kamera fullframe. Penentuan posisi kamera untuk menghasilkan foto dengan tampalan yang cukup 
juga mempengaruhi nilai error. Posisi kamera dalam pengambilan foto $360^{\circ}$ dapat dilihat pada

\section{Gambar III.4 berikut:}

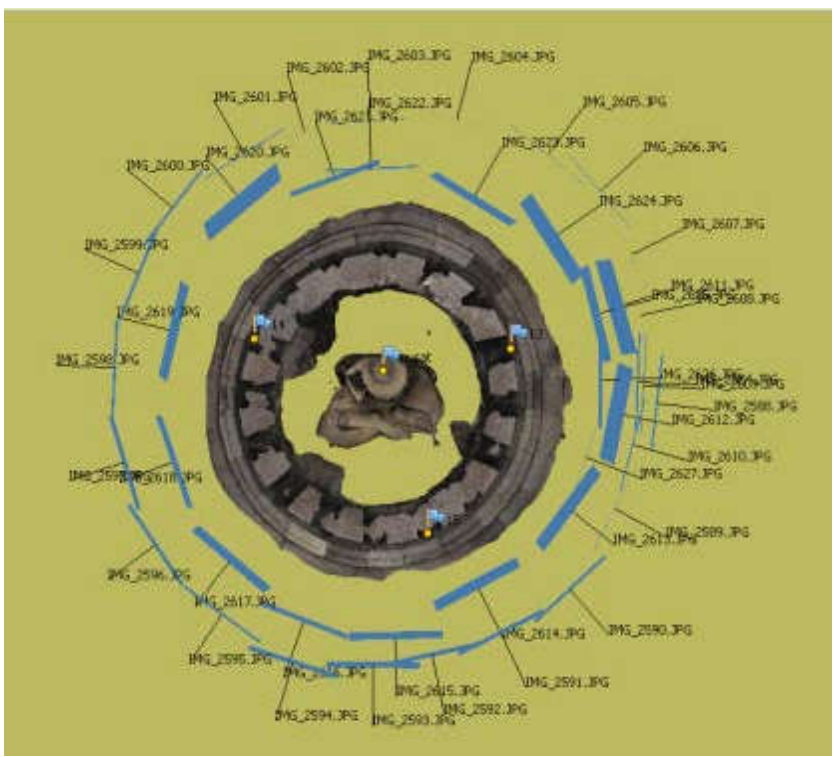

Gambar III.4. posisi kamera pada pengambilan foto stupa teras terbuka

\section{c. Arca Singa Candi Borobudur}

Proses perataan berkas dan pemodelan tiga dimensi pada arca singa mempunyai proses yang sama dengan stupa teras terbuka karena merupakan obyek dengan sudut pengambilan foto $360^{\circ}$. Kontrol yang digunakan juga menggunakan skala, dengan hasil perataan berkas seperti pada Tabel III.7 sebagai berikut :

Tabel III.7. Hasil Perataan Berkas dan Pemodelan 3D Arca Singa dengan kontrol Skala dan kamera lab calibration

\begin{tabular}{|c|c|c|}
\hline Label & Distance $(\mathbf{m})$ & error $(\mathbf{m})$ \\
\hline Point 18 - point 19 & 0.68577 & -0.002224 \\
\hline Point 16 - point 19 & 1.15737 & 0.000367 \\
\hline Point 16 - point 17 & 0.73913 & -0.000875 \\
\hline Point 17 - point 18 & 1.13258 & 0.002577 \\
\hline Point 17 - point 20 & 1.05889 & -0.001107 \\
\hline \multicolumn{2}{|c|}{ RMSE Total } & $\mathbf{0 . 0 0 1 6 5 5 9}$ \\
\hline
\end{tabular}

Dari hasil proses perataan berkas dan pembentukan model tiga dimensi (3D) stupa teras terbuka menghasilkan data point cloud, dense point cloud, mesh, dan tekstur. Hasil tersebut dapat dilihat pada gambar III.5 di bawah:
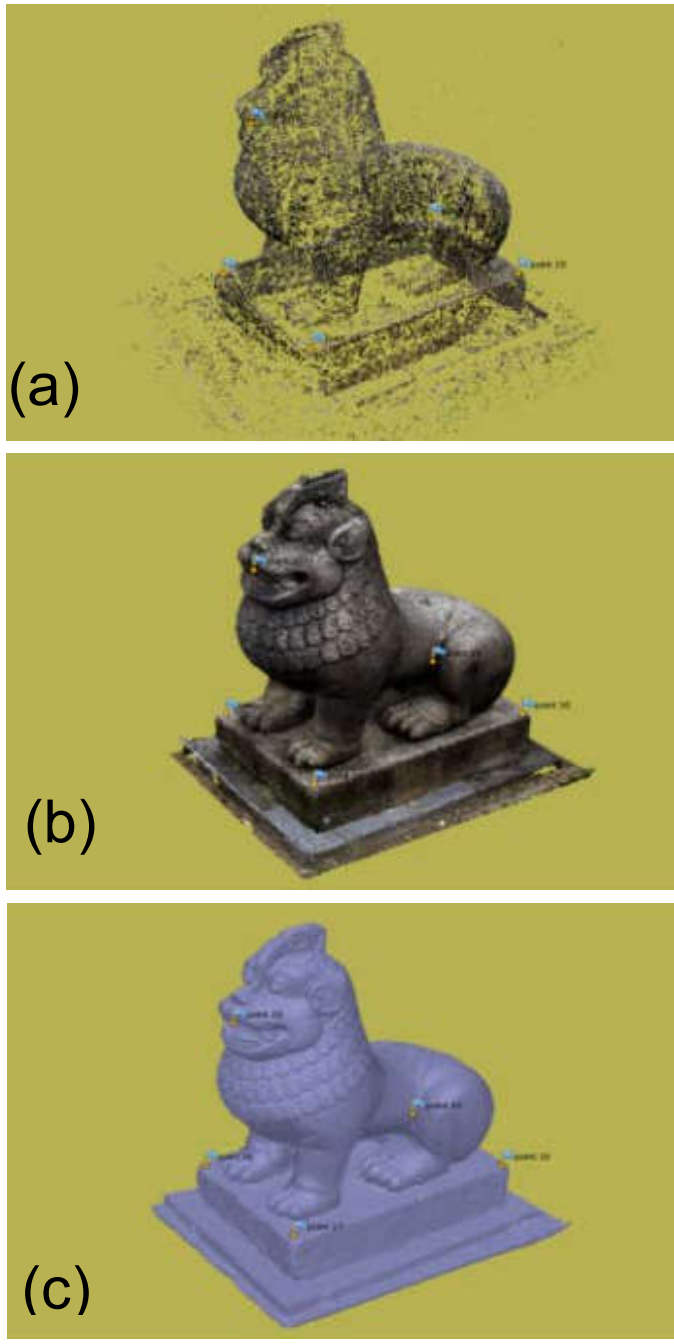

(d)

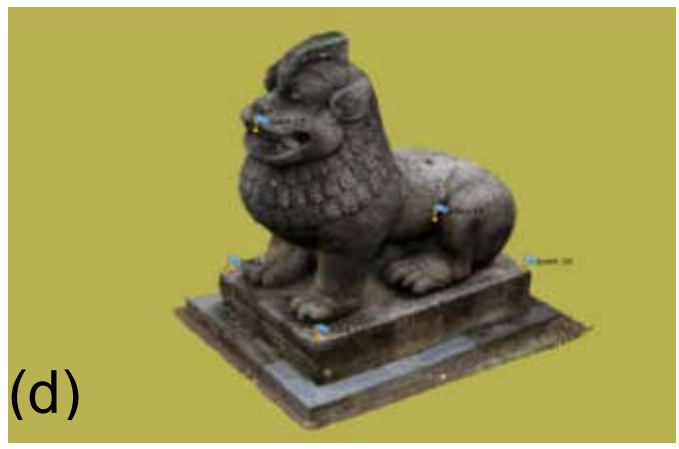

Gambar III.5. Hasil pemodelan 3D arca singa (a) tie points, (b) dense clouds, (c) mesh format, (d) tekstur

Hasil pemodelan tiga dimensi arca singa dengan kamera lab calibration dan kontrol menggunakan skala diperoleh nilai total error cukup kecil dibawah $1 \mathrm{~cm}$, yaitu sebesar $\mathbf{0 . 0 0 1 6 5 5 9}$ atau sekitar 1,5 mm. Nilai tersebut dipengaruhi oleh kondisi kamera yang stabil, hasil lensa yang terkalibrasi, area tampalan foto yang cukup luas, serta sensor kamera fullframe. 
2. Foto Udara (Aerial Photogrammetry)

a. Candi Borobudur

Hasil pemodelan dan perataan berkas dengan

parameter kamera lab calibration dan self calibration, kontrol menggunakan GCP didapatkan hasil seperti pada Tabel III.8a dan III.8b di bawah:

Tabel III.8a. Hasil Perataan Berkas dan Pemodelan 3D Foto Udara Candi Borobudur dengan kontrol GCP dan kamera lab calibration

\begin{tabular}{|c|c|c|c|c|c|}
\hline Label & $\mathbf{X Y}$ error $(\mathbf{m})$ & $\mathbf{Z}$ error $(\mathbf{m})$ & Error $(\mathbf{m})$ & Proyeksi & Error $(\mathbf{p i x})$ \\
\hline Point 1 & 0.0876266 & -0.0526374 & 0.102221 & 23 & 2.090 \\
\hline Point 4 & 0.0293017 & 0.0978429 & 0.102136 & 26 & 1.375 \\
\hline Point 7 & 0.0339662 & -0.0693848 & 0.077252 & 32 & 1.570 \\
\hline Point 13 & 0.0415201 & 0.0724618 & 0.083514 & 26 & 2.029 \\
\hline Point 16 & 0.0665172 & -0.0890324 & 0.111136 & 32 & 2.671 \\
\hline Point 19 & 0.1000270 & 0.0414351 & 0.108269 & 25 & 1.693 \\
\hline RMSE Total & $\mathbf{0 . 0 6 5 6 3 0 9}$ & $\mathbf{0 . 0 7 3 0 8 9 6}$ & $\mathbf{0 . 0 9 8 2 3}(\mathbf{1 0} \mathbf{c m})$ & & $\mathbf{1 . 9 6 8}$ \\
\hline
\end{tabular}

Tabel III.8b. Hasil Perataan Berkas dan Pemodelan 3D Foto Udara Candi Borobudur dengan kontrol GCP dan kamera self calibration

\begin{tabular}{|c|c|c|c|c|c|}
\hline Label & $\mathbf{X Y}$ error $(\mathbf{m})$ & $\mathbf{Z}$ error $(\mathbf{m})$ & Error $(\mathbf{m})$ & Proyeksi & Error $(\mathbf{p i x})$ \\
\hline Point 1 & 0.168861 & -0.032896 & 0.171975 & 23 & 3.068 \\
\hline Point 4 & 0.101529 & 0.104793 & 0.14591 & 26 & 2.042 \\
\hline Point 7 & 0.177728 & -0.094633 & 0.201353 & 32 & 2.432 \\
\hline Point 13 & 0.216025 & 0.108425 & 0.241708 & 26 & 2.848 \\
\hline Point 16 & 0.0702591 & -0.146261 & 0.162261 & 32 & 3.891 \\
\hline Point 19 & 0.215972 & 0.063512 & 0.225117 & 25 & 2.467 \\
\hline RMSE Total & $\mathbf{0 . 1 6 7 6 4 8}$ & $\mathbf{0 . 0 9 8 4 8 9 7}$ & $\mathbf{0 . 1 9 4 4 3 8}(\mathbf{2 0} \mathbf{c m})$ & & $\mathbf{2 . 8 8 0}$ \\
\hline
\end{tabular}

Hasil perataan berkas pemodelan Candi Borobudur menggunakan dua parameter kamera, yaitu kamera terkalibrasi dan kamera tidak terkalibrasi dengan titik kontrol keduanya menggunakan GCP. Dari Tabel III.8a dengan parameter kamera terkalibrasi didapatkan nilai Total error koordinat sebesar 0.09823 m (10 $\mathrm{cm}$ ), tingkat error tersebut dipengaruhi oleh posisi definisi marker GCP hasil pemotretan yang tidak sesuai pada posisi obyek sebenarnya, karena marker yang dibuat tidak terlihat jelas pada foto udara yang dihasilkan. Sedangkan nilai total error pixel sebesar 1.968 mempunyai nilai lebih dari 1, dan dinilai kurang baik. Hal ini dapat disebabkan karena jarak pengambilan foto udara terlalu tinggi terhadap obyek, sehingga distorsi radial pada foto cenderung lebih banyak terjadi. Pengambilan foto menggunakan mission planner pix 4 d capture dengan sudut pengambilan vertikal dan area tampalan foto sebesar $\mathbf{8 0} \%$. Dari proses pengambilan tersebut diketahui posisi kamera seperti yang terlihat pada Gambar III.6 di bawah:

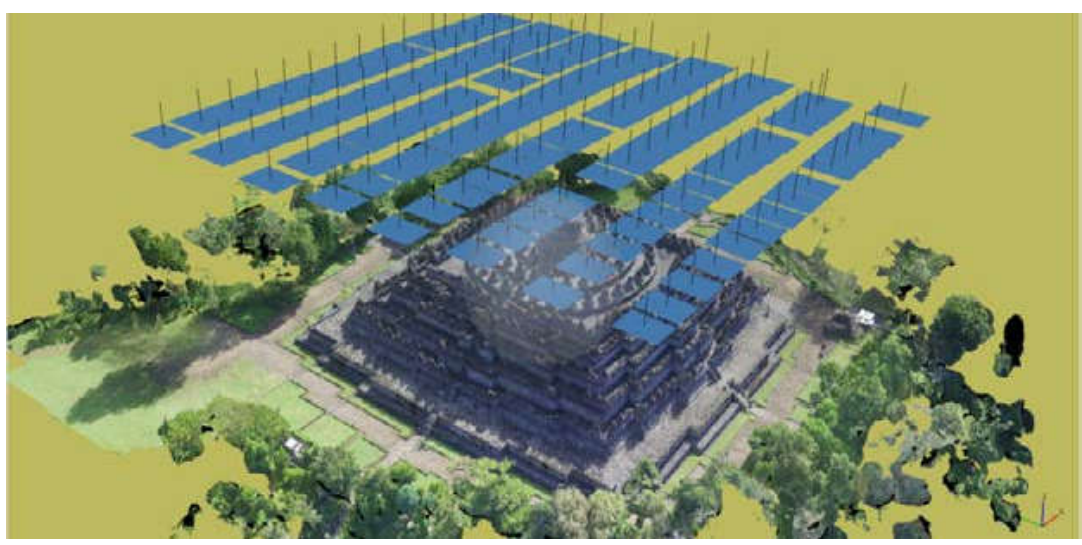

Gambar III.6. Posisi kamera pada pengambilan foto udara Candi Borobudur 


\section{PENUTUP}

\subsection{Kesimpulan}

Dari hasil pengumpulan, pengolahan, dan analisis data dapat ditarik beberapa kesimpulan sebagai berikut :

1. Hasil perataan berkas dan pemodelan tiga dimensi berbasis foto rentang dekat pada obyek relief kapal Candi Borobudur dengan kontrol skala (jarak) dan kamera terkalibrasi menghasilkan nilai RMS error yang cukup kecil, yaitu sebesar $\mathbf{5} \mathbf{~ m m}$, sedangkan hasil perataan berkas dan pemodelan pada obyek stupa teras terbuka dan arca singa masing-masing mempunyai nilai RMS error yang lebih kecil, yaitu 3 $\mathrm{mm}$ dan $\mathbf{1 , 6} \mathrm{mm}$.

2. Hasil perataan berkas dan pemodelan tiga dimensi berbasis foto udara dengan menggunakan wahana UAV pada Candi Borobudur, titik kontrol menggunakan koordinat GCP dan kamera terkalibrasi menghasilkan nilai RMS error sebesar $0.09823 \mathrm{~m}(10 \mathrm{~cm})$.

3. Metode foto rentang dekat (close range photogramtery) dan foto udara (aerial photogramtery) dengan wahana pesawat tanpa awak untuk perekaman data dan pendokumentasian tiga dimensi Cagar Budaya layak untuk digunakan. Untuk mendukung kelayakan hasilnya, maka harus diikuti dengan langkah pengambilan data yang benar, diantaranya proses

\section{DAFTAR PUSTAKA}

Aber, J. S., Marzolff, I. R., Johannes, B. (2010). Small Format Aerial Photography: Principles, Techniques and Geoscience Applications. Amsterdam: Elsevier.

Atkinson, K. B. (1996). Close Range Photogrammetry and Machine Vision. Scotland, UK: Whittles Publishing.

Bolognesi, et al. (2014). Accuracy of Cultural Heritage 3D Models by RPAS and Terrestrial Photogrammetry. Jurnal. The International Archives of the Photogrammetry, Remote Sensing and Spatial Information Sciences, Vol. XL-5, 2014. Italy: ISPRS Technical Commission V Symposium.

Chao, H. Y. (2010). Autopilots for Small Unmanned Aerial Vehicles: A Survey. Jurnal. International Journal of Control, Automation and Systems, Vol. 8, 2010. ICROS. kalibrasi kamera, metode pengambilan foto dan penggunaan kontrol geometri untuk mendapatkan akurasi yang tinggi dan nilai error yang seminimal mungkin.

\subsection{Saran}

Berdasarkan hasil pengumpulan data, analisa dan kesimpulan yang telah disampaikan, ada beberapa saran sebagai bahan pengembangan metode perekaman data dan pendokumentasian tiga dimensi Cagar Budaya di Indonesia yaitu:

1. Metode pendokumentasian Cagar Budaya tiga dimensi berbasis foto dengan perangkat kamera dan UAV menghasilkan format data yang sama dengan data yang dihasilkan oleh perangkat perekaman data tiga dimensi terrestrial laser scanner, untuk itu perlu dikembangkan metode untuk menggabungkan data dari kedua metode tersebut.

2. Data yang dihasilkan dari metode perekaman dan pendokumentasian tiga dimensi dapat digunakan sebagai media interpretasi dan presentasi, karena mampu menampilkan obyek yang realistis. Pengembangan perlu dilakukan dengan cara membuat data base sistem informasi tiga dimensi Cagar Budaya di seluruh Indonesia yang berbasis web, sehingga dapat diakses dengan mudah dan bermanfaat bagi pihak-pihak yang memerlukannya.

Hanief, H., Nurdiati, S., Suwardhi, D. (2013). Rekonstruksi Model 3D Menggunakan Foto Udara Untuk Menduga Tinggi Objek. Jurnal. Majalah Ilmiah Globe, Vol. 15 No. 2, 2013. Bogor: Badan Informasi Geospasial.

Hendy, I. N. G. (2014). Pembuatan Model Tiga Dimensi Candi Gebang Menggunakan Metode Fotogrametri Jarak Dekat. Skripsi. Yogyakarta: Universitas Gadjah Mada.

Prastyo, A. D., Subiyanto, S., Suprayogi, A. (2012). Aplikasi Fotogrametri Jarak Dekat untuk Pemodelan 3D Candi Gedong Songo. Jurnal. Jurnal Geodesi, Vol. 1, No. 1, Tahun 2012. Semarang: Universitas Diponegoro.

Soeta'at. (1994). Diktat Fotogrametri Analitik. Jurusan Teknik Geodesi, Fakultas Teknik. Yogyakarta: Universitas Gadjah Mada. 
Sukoco, E. (2003). Aplikasi Fotogrametri Jarak Dekat untuk Pemodelan Benda Cagar Budaya Beserta Reliefnya. Skripsi. Jurusan Teknik Geodesi Fakultas Teknik. Yogyakarta: Universitas Gadjah Mada.
Wolf, P. R. (1983). Elements of Photogrammetry. New York, US: McGraw-Hill. 